\title{
Efficiency of Seed oil (Pentaclethramacrophlla) Shell in Removal of Nickel (II) ionAqueoussolution
}

\author{
${ }^{* 1}$ Adeyemi, S. A. and ${ }^{2}$ Dauda, K.T \\ ${ }^{I}$ Department of Chemistry, Tai Solarin College of Education Omu-Ijebu, P.M.B. 2128 Ijebu-ode, Nigeria. \\ ${ }^{2}$ Department of Chemistry, Bells University of Technology Ota, P.M.B. 1015 Ota Ogun State Nigeria.
}

\begin{abstract}
An Abundance agricultural waste Pentaclethramacrophylla shells in rural areas of Eastern, Southern and Northern partof Nigeria; studied for the removal of nickel (II) ion in aqueous solution in a batch system by Atomic Absorption spectrophotometer (mechanic Perkin Elmer analyst 2000). The influence of pH, initial ion concentration, adsorbent dosage and contact time was studied at $30^{\circ} \mathrm{C}$. sorption increased with increasing dosage, initial ion concentration and optimum plateau sorption of $97.83 \%$ reached at $p H 7.5$ within 60min. Mathematical models describing kinetic and equilibrium of sorption were proposed;kinetic sorption data fitted well to the Ho pseudo-second-order model with correlation coefficient of $R^{2}=1$ and was found that adsorption of $\mathrm{Ni}(\mathrm{II})$ ion onto PMS correlated well $\left(R^{2}=0.9797\right)$ with the Freundlich isotherm model compared to Langmuir isotherm model under the same varied initial $\mathrm{Ni}$ (II) ion concentration studied.Furthermore,practical implication of this research work is the development of efficient, economical and sustainable environment technology for $\mathrm{Ni}^{2+}$ removal from contaminated water, which is especially useful when Pentaclethramacrophylla shells is locally available "waste to health to wealth".
\end{abstract}

Key words: Adsorption, efficiency, isotherm, Pentaclethramacrophyllashell (PMS).

\section{Introduction}

Nature treats water in its own way through the hydrologic cycle, though we still need to treat the water before use due to all the pollution in the environment, likewise water bodies are major sites of heavy metal deposits due to the fact that streams and rivers flows through agricultural areas where pesticides and fungicides may have been used, through industrial districts where there may have been many metal deposits and direct discharges of effluents into these water bodies [1].

Metal find many useful applications in our daily life, increased industrialization and various domestic activities have contributed largely toward introduction of heavy metals into the aquatic medium, as well as into the terrestrial environment.

Heavy metals are considered to be particularly dangerous pollutants. Their presence in the wastewater of several industrial processes, such as electroplating, metal finishing, metallurgical work, tanning, chemical manufacturing, mining and battery manufacturing, has brought about more environmental concerns due to their toxicity even at low concentrations $[2,3,4]$.

Moreover,the presence of nickel exceeding its critical level might bring about serious lung and kidney problems aside from gastrointestinaldistress, pulmonary fibrosis and skin dermatitis [5].

Live and dead biomaterials have been proved possible solution in remediating heavy metal contaminated aquatic environment, mainly caused through the industrial discharges, metal smelting, agricultural and other anthropogenic activities that involves heavy metals.

Heavy metal pollution of aquatic medium has been a major concern in recent years due to their nonbiodegradability and toxicity. Most of the heavy metal salt are soluble in water and form aqueous solutions and consequently cannot be separated by ordinary physical separation methods [6].

The remediation and removal of heavy metals from aqueous media has received considerable attention in recent years, however convectional (electrochemical treatment, chemical precipitation, ion exchange, electrodialysis,reverse osmosis etc.) methods have been found to be sometimes restricted, because of expensive investment, operational costs, potential generation of secondary pollution, and its disposal is not eco-friendly[7].

Furthermore, available low cost and high efficiency of some waste agricultural materials in removal of heavy metals have been reported; such as: sawdust of spruce [8], maize and husk[9], fluted pumpkin seed shell [10], maize leaf[11],coconut husk[12],melon seed husk[13], black gram husk [14] and so on.

Availablein abundance of Pentaclethramacrophylla shellsas agricultural waste material in rural areas of Eastern,Southern and Northern partof Nigeria made itsease in this research as biosorbent for the removal of $\mathrm{Ni}(\mathrm{II})$ ion solution. This study investigated the effect $\mathrm{P}^{\mathrm{H}}$ of solution, contact time, adsorbent dosage and initial metal concentration; meanwhile the metal sorption was assessed based on the Langmuir and Freundlich adsorption isotherm model at $30^{\circ} \mathrm{C}$. 


\section{Symbols and abbreviations:}

PMS Pentaclethramacrophylla shell

SOS seed oil shell

$\mathrm{C}_{\mathrm{o}} \quad$ initial metal ion concentration

$\mathrm{C}_{\mathrm{a}} \quad$ concentration of metals ions adsorbed $(\mathrm{mg} / \mathrm{L})$

$\mathrm{q}_{\mathrm{e}} \quad$ metal uptake in $\mathrm{mg} / \mathrm{g}$ equilibrium

$\mathrm{q}_{\mathrm{t}} \quad$ metal uptake in $\mathrm{mg} / \mathrm{g}$ at time $\mathrm{t}$

$\mathrm{C}_{\mathrm{e}} \quad$ metal ion concentratsion in solution at equilibrium

$\mathrm{q}_{\max } \quad$ maximum adsorption capacity $(\mathrm{mg} / \mathrm{g})$

$\mathrm{R}^{2} \quad$ regression correlation coefficient

$\mathrm{t} \quad$ time (min)

$\mathrm{V} \quad$ volume of the solution in $\mathrm{ml}$

$\mathrm{K}_{\mathrm{L}} \quad$ separation factor

b Langmuir constant (L/mg)

$\mathrm{n} \quad$ Freundlich constants, intensity of adsorption $(\mathrm{mg} / \mathrm{g}) /(\mathrm{mg} / \mathrm{L})^{1 / \mathrm{n}}$

$\mathrm{K}_{\mathrm{f}}$ empirical constant that provides an indication of the adsorption capacity biosorbent, $\mathrm{K}_{1}$ pseudo-first order rate constant $\left(\mathrm{min}^{-1}\right)$

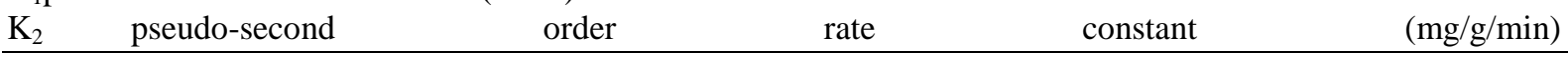

\section{Materials And Methods}

\subsection{Biomass}

Samples of Pentaclethramacrophylla shells were collected from local seed oil food spice production site, in Oke-Odan, Yewa South local government area of Ogun State, Nigeria. Where hugelygenerated as primary agricultural waste, Seed Oil shells were extensively washed with distilled water to removed dirt and other extraneous matter that might interact with sorbed metal ion and grounded into powdery form, using precleaned local mortar and pestle and sieved with a mesh to maximum particle size of $2 \mathrm{~mm}$ the unformed material produced was stored in air-tight moisture free plastic containers and subsequently used for biosorption studies.

\subsection{Chemical reagents and adsorbate}

Analytical grade Nickel nitrate salt was used for the stock solutions $(1000 \mathrm{mg} / \mathrm{l}), 1.4285 \mathrm{~g}$ of Ni($\left(\mathrm{NO}_{3}\right)_{2}$ was accurately weighed and dissolved in little distilled water inside a beaker. The solution was quantitatively transferred into 1litre volumetric flask and made up to the mark with distilled water and the solutions for all experiments were prepared through dilution of stock solution.

\subsection{Sorption Studies}

The batch adsorption experiments were conducted with powered Pentaclethramacrophylla shell at $30^{\circ} \mathrm{C}$.The effect of $\mathrm{pH}$ on the adsorption capacity was investigated at $\mathrm{pH}$ values of 3,4,5,7,8 and 9 using known volume of $100 \mathrm{mg} \backslash \mathrm{L} \mathrm{Ni}$ (II) solutions, the $\mathrm{P}^{\mathrm{H}}$ of solution was adjusted to a set of value by adding $0.1 \mathrm{M} \mathrm{HNO}_{3}$ and $0.1 \mathrm{M} \mathrm{NaOH}$. $1 \mathrm{~g}$ sorbent was added to $25 \mathrm{ml}$ of desired $\mathrm{pH}$ and gently agitated on mechanical shaker for 1 hour. The effect contact time was of studied in the time range 60-180minat the optimum $\mathrm{pH}$ value 7.5. Effects of dosages (ranges $0.4 \mathrm{~g}-2.0 \mathrm{~g}$ ) were also determined.

Similarly above, metal concentrations were also investigated in the range of $100 \mathrm{mg} / 1-500 \mathrm{mg} / \mathrm{l}$. At the end of adsorption process,the suspensions were filtered and metal ion concentration of filtrate was determined using Atomic Absorption spectrophotometer, mechanic Perkin Elmer analyst (2000)and adsorption capacity was determined bymass balance calculation

$\mathrm{Q}=\frac{(\mathrm{Co}-\mathrm{Ce}) \mathrm{V}}{\mathrm{W}}$

Where, $Q$ is adsorption capacity $(\mathrm{mg} / \mathrm{g}), \mathrm{C}_{\mathrm{o}}$ and $\mathrm{C}_{\mathrm{e}}$ initial equilibrated concentration of metal ions (mg/l) respectively, $\mathrm{V}$ is volume of added solution(l) and $\mathrm{W}$ is the weight of dry powered Pentanclethramacrophylla shell

The $\mathrm{Ni}(\mathrm{II})$ ions removed percentage can be calculated as:

Removal \% $=\left(\frac{\mathrm{Co}-\mathrm{Ct}}{\mathrm{Co}}\right) \times 100$

Where $\mathrm{C}_{\mathrm{t}}(\mathrm{mg} / \mathrm{l})$ is liquid- phase concentration of $\mathrm{Ni}(\mathrm{II})$ ion at time $\mathrm{t}$.

\subsection{Effect of $\mathrm{pH}$ on adsorption}

\section{Results And Discussion}

The $\mathrm{pH}$ of aqueous solutions is an important controlling parameter in the adsorption process because it affects the solubility of the metals ions, the concentration of counter ions on the surface of the adsorbent and the degree of ionization of the adsorbate during the reaction [15]. Fig.1. showed the effect of the initial pHsolution 
on $\mathrm{Ni}^{2+}$ removal by Pentaclethramacrophylla shells. At $\mathrm{pH}$ 7.5-8.0, plateau adsorption rate was observed on $\mathrm{Ni}(\mathrm{II})$ metal ion, sorption \% rate increased from $\mathrm{pH} 3-5$ and discontinued to $97.30 \%$ at $\mathrm{pH} 6$ and sharply increased at $\mathrm{pH} 7.5$ - 8 while slightly drop occurred at $\mathrm{P}^{\mathrm{H}} 9$ to $97.60 \%$.

The effect of initial pHon biosorption provides an insight on the nature of physicochemical interaction between solute in solution and adsorptive sites of the adsorbent and could be attributed to the change in the degree of ionization of the biosorbent and sorbate.

\subsection{Effect of initial concentration of $\mathrm{Ni}$ (II) ion}

Initial concentrationstudied range from $100 \mathrm{mg} / \mathrm{L}$ to $500 \mathrm{mg} / \mathrm{L}$ under pre-determined optimized conditions of 1 hour contact time and $\mathrm{pH} 8$ gives adsorption percentage of 99.5 for $100 \mathrm{mg} / \mathrm{l}$ and $99.4 \%$ for $200 \mathrm{mg} / \mathrm{l}$ while removal efficiency increases with increases in concentration from $300 \mathrm{mg} / \mathrm{L}$ to $500 \mathrm{mg} / \mathrm{L} \mathrm{recorded}$ and shown in fig. 3. This is attributed to the increase in number of metal ions competing for available sites on the adsorbent at higher concentration levels[16].

According to the values of $\mathrm{R}^{2}, \mathrm{~K}_{\mathrm{f}}$, and $\mathrm{K}_{\mathrm{L}}$ shown in tab. 2, it was observed that the Langmuir isotherm show good fit to the experimental equilibrium adsorption data than the Freundlich isotherm equation. $\mathrm{K}_{\mathrm{L}}$ value which less than one and greater than zero indicating favorable sorption of Ni(II) ion onto PMS.

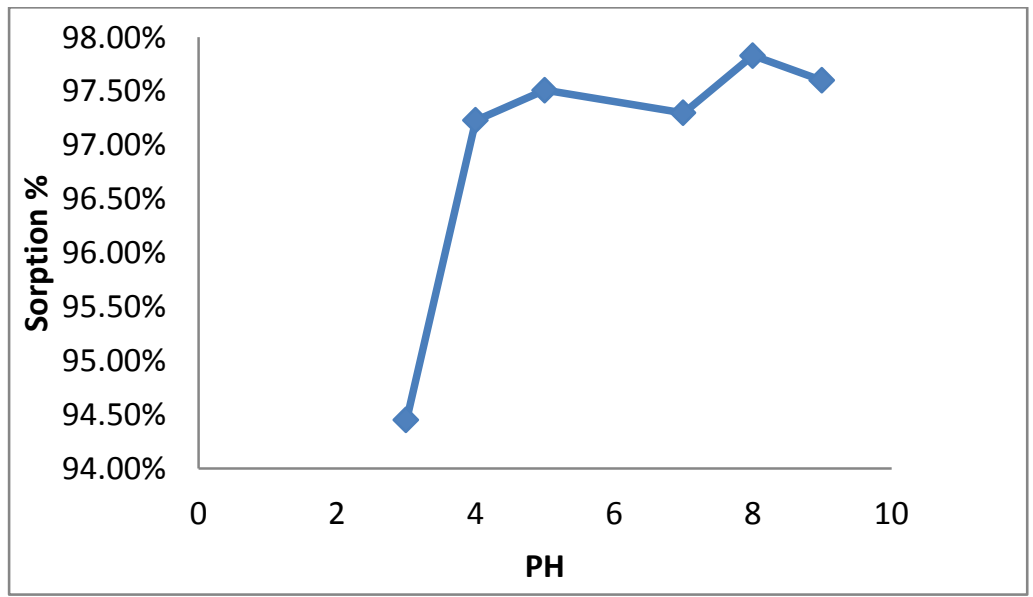

Fig.1: showing the effect of $\mathrm{pH}$ on the biosorption of $\mathrm{Ni}(\mathrm{II})$ ions from aqueous solution using PMS.

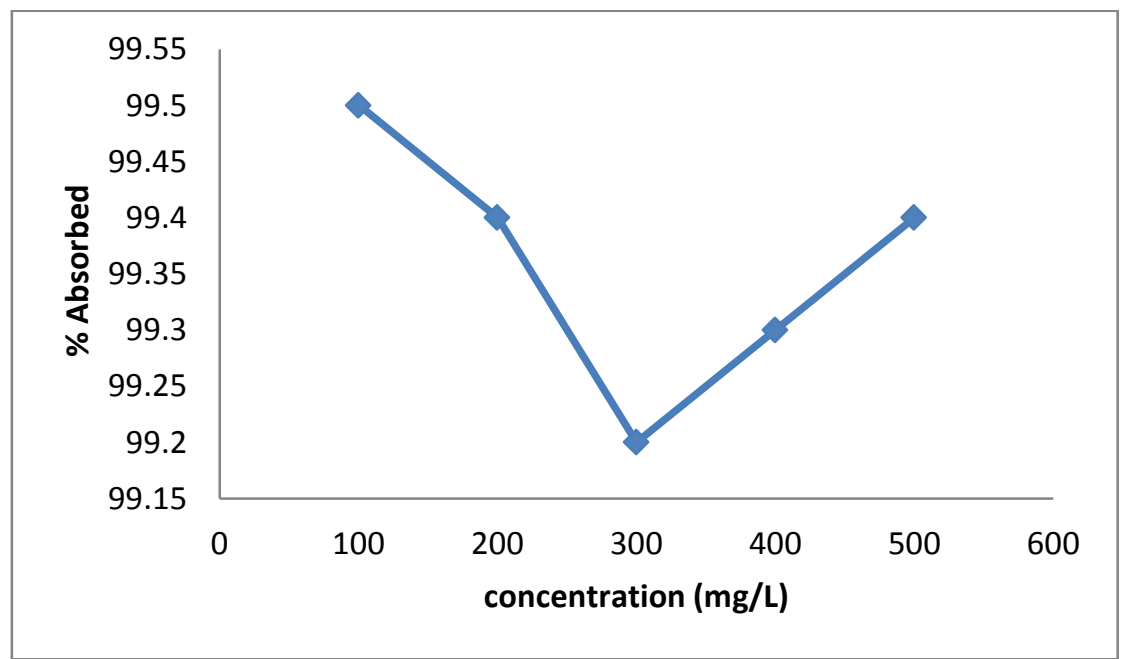

Fig. 2: Effect of initial Ni (II) ion concentration on the sorption by SOS powder at $1 \mathrm{~g} / 25 \mathrm{~mL}$ of sorbent concentration at $30^{\circ} \mathrm{C}$ and contact time of 1 hour. 


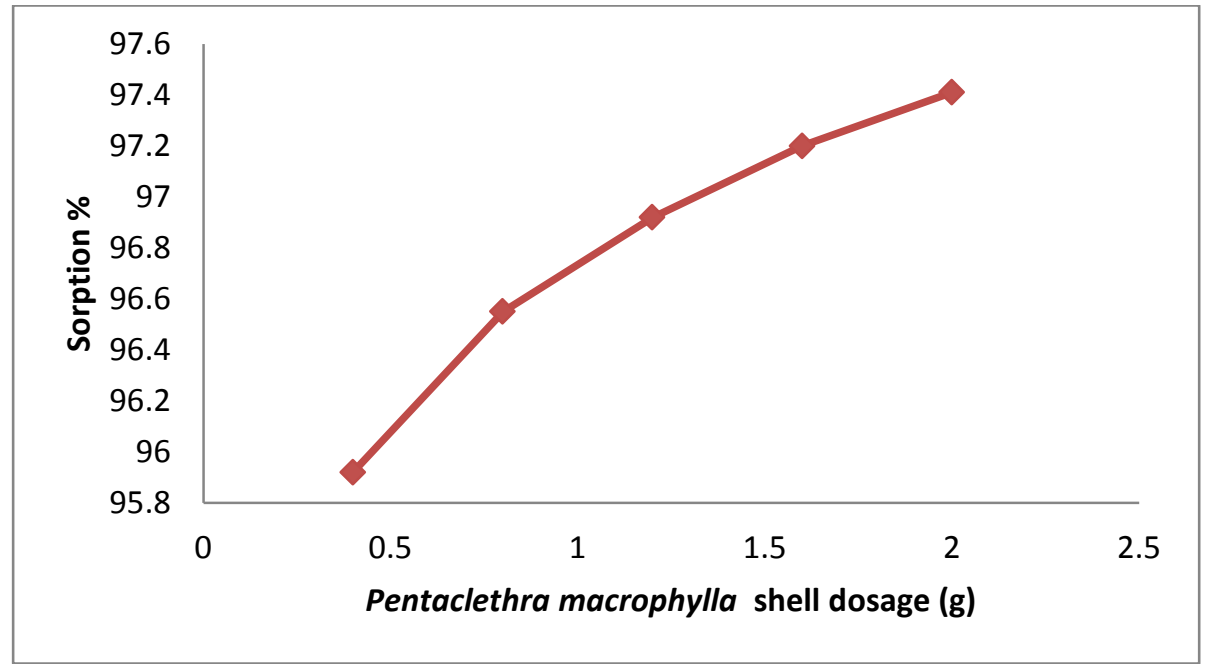

Fig 3: Effect of biosorbent dosage on metal ions sorption by Pentaclethramacrophylla shell for $100 \mathrm{mg} / \mathrm{L}$ Nickel metal ion on $\mathrm{pH} 8$ at $30^{\circ} \mathrm{C}$

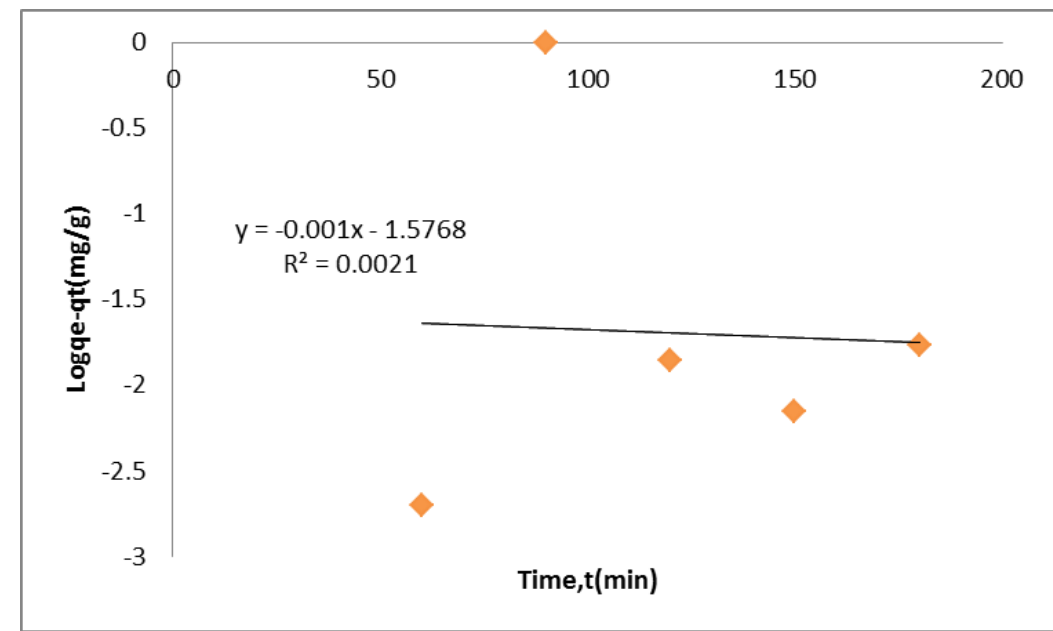

Fig 4: Pseudo-first order for the biosorption of Ni (II) by Pentaclethramacrophylla shell for $100 \mathrm{mg} / \mathrm{L}$ of metal and $1 \mathrm{~g}$ of $25 \mathrm{ml}$ on sorbent.

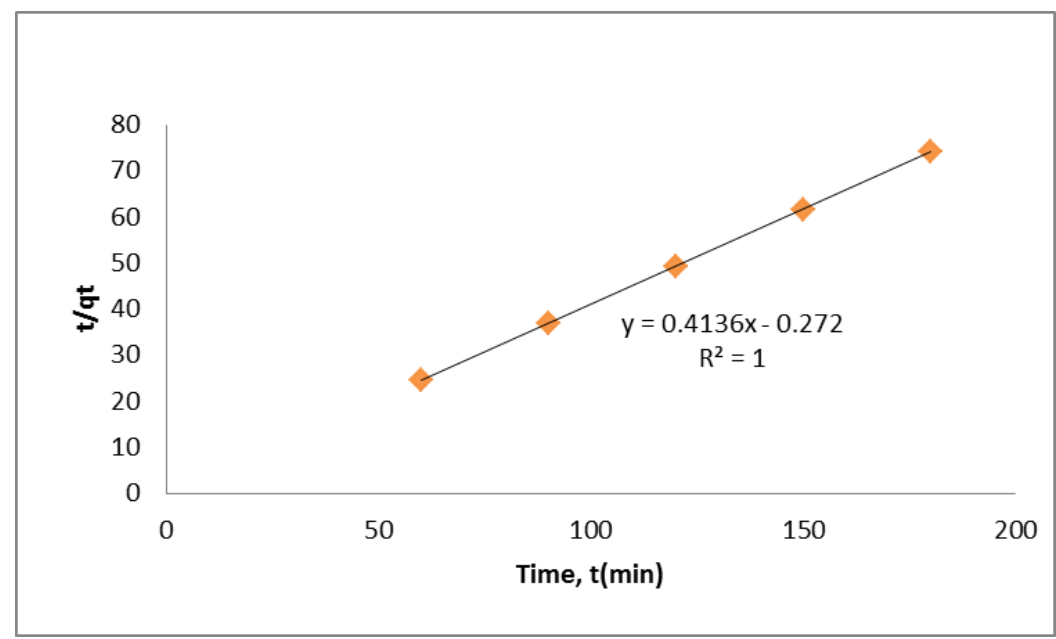

Fig. 5: Pseudo second order for the biosorption of heavy metals on Ni(II) by seed oil shell for $100 \mathrm{mg} / \mathrm{L}$ of metal and $1 \mathrm{~g}$ of $25 \mathrm{ml}$ of the sorbent. 


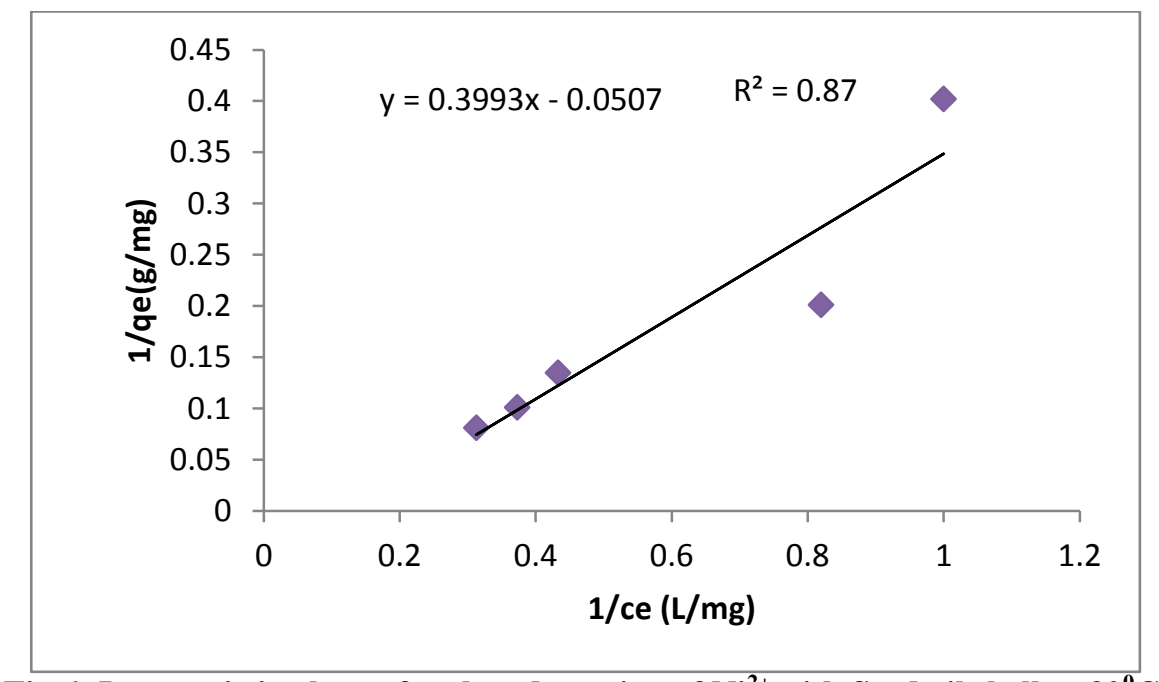

Fig.6: Langmuir isotherm for the adsorption of $\mathrm{Ni}^{2+}$ with Seed oil shell at $30^{\circ} \mathrm{C}$.

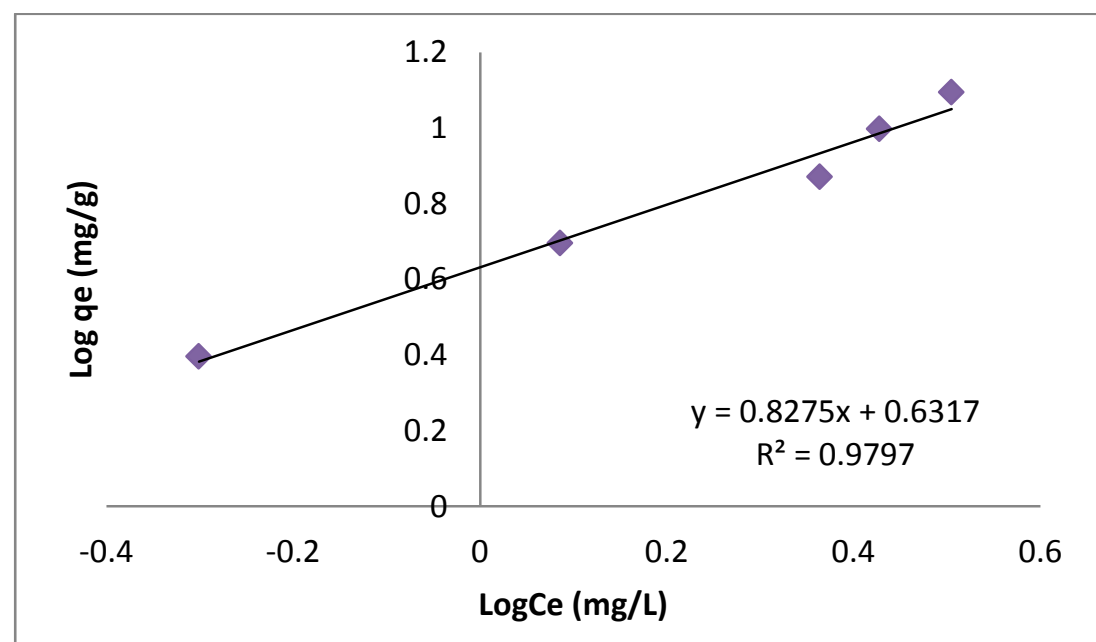

Fig.7: Freundlich isotherm for the adsorption of $\mathrm{Ni}^{2+}$ with Seed oil shell at $30^{0} \mathrm{C}$.

\subsection{Effect of contact time}

The results obtained for the variation of contact time 60, 90,120, 150,180 min of nickel ions on PMS are shown in table 6. More than $97 \%$ ions sorbed onto PMS within first 60 minutes.

\subsection{Effect of adsorbent dosage}

As gram of Pentacleclethramacrophylla shell dose increases, it was discovered that the sorption percentage of $\mathrm{Ni}$ (II) ions removal also increased in order of $95.92 \%>96.55 \%>96.92>97.20 \%>97.41 \%$ and such is mostly attributed to an increase in the sorptive surface area and the availability of more active binding sites on the surface of the biosorbent.

The results are presented in table 5 and the effect of varying the PMS dosage on the sorption of Nickel metal ions is shown in fig. 3 , respectively.

\subsection{Kinetic studies of $\mathrm{Ni}$ (II) ion biosorption}

Several kinectic models are available to understand the behavior of the adsorbent and also to examine the controlling mechanism of the biosorption process. The mechanisms used for the kinetic biosorption of $\mathrm{Ni}$ (II) ions are the Pseudo first-order and Pseudo- second order. Both models are test for fitness by their correlation. $\mathrm{R}^{2}$ is approximately one $\left(\mathrm{R}^{2} \approx 1\right)$ [17].

3.5.1Largergren Pseudo-first order equation; linear given as:

$\log \left(\mathrm{q}_{\mathrm{e}}-\mathrm{q}_{\mathrm{t}}\right)=\log \left(\mathrm{q}_{\mathrm{e}}\right)-\frac{\mathrm{k} 1 \mathrm{t}}{2.303}$

The plot of $\log \left(\mathrm{qe}-\mathrm{q}_{\mathrm{t}}\right)$ versus time $\mathrm{t}$ for $\mathrm{Ni}$ (II) ion of the sorbent used and the pseudo-first order parameter $\mathrm{K}_{1}$, qe calculated and the regression coefficient $\left(\mathrm{R}^{2}\right)$ are shown in fig. 4 and table 3, respectively. Where $\mathrm{q}_{\mathrm{t}}$ and $\mathrm{q}_{\mathrm{e}}$ are the amount of $\mathrm{Ni}$ (II) ion adsorb $(\mathrm{mg} / \mathrm{g}$ ) at time $\mathrm{t}(\mathrm{min})$ and at equilibrium respectively. The 
constant $\mathrm{K}_{1}$ obtained from the slope, $\mathrm{q}_{\mathrm{e}}$ calculated result differ from experimental qe value, which indicate that, pseudo first-order is not appropriate to explain the biosorption process, meanwhile, $\mathrm{R}^{2}$ also proved that firstorder model not appropriately discussed the sorption process.

The Ho Pseudo second-order model for sorption kinetics is expressed as:

$\frac{\mathrm{t}}{\mathrm{qt}}=\frac{1}{\mathrm{~K} 2 \mathrm{qe} 2}+\frac{\mathrm{t}}{\mathrm{qt}}(4)$

Where, $\mathrm{K}_{2}$ (g/mg.min) is the second order rate constant. The second order constants are used to calculate the initial biosorption rate, given by: $\mathrm{h}=\mathrm{K}_{2} \mathrm{q}_{\mathrm{e}}^{2}$

Plot of pseudo second order for $\mathrm{Ni}$ (II) ions for this study shown in figure 4 , which gives $\frac{1}{\mathrm{qe}}$ as slope and $\frac{1}{\mathrm{~K} 2 \mathrm{qe} 2}$ as intercept from which $\mathrm{K}_{2}$ expressed. The plots identify distinct fits between the precise curves and the experimental data points. Its analyzed excellent linearization of the experimental data, therefore showing the proposal that chemisorption is the rate limiting step and that the mechanism follows a pseudo second order reaction model. The equilibrium sorption capacity $\mathrm{q}_{\mathrm{e}}$ calculated, the initial sorption capacity $\mathrm{h}$, the rate constant $K_{2}$ and the regression coefficient $R^{2}$ are formed from the plot are shown in table 5 .

There is no significant different between equilibrium capacity $\mathrm{q}_{\mathrm{e}}$ calculated and the $\mathrm{q}_{\mathrm{e}}$ experimental, also a unit value of $\mathrm{R}^{2}$ support pseudo second order reaction model.

In comparison; $\mathrm{R}^{2}, \mathrm{q}_{\mathrm{e}}(\mathrm{cal})$ and $\mathrm{q}_{\mathrm{e}}(\mathrm{exp})$ parameters of both pseudo order kinetic model; Regression coefficient of first order kinetic value so small to a unit value of second order kinetic model, meanwhile closeness of $\mathrm{q}_{\mathrm{e}}(\mathrm{cal})$ to $\mathrm{q}_{\mathrm{e}}(\mathrm{exp})$ value in second order kinetic model shows that kinetic of nickel ion by Pentaclethramacrophylla shell is better described pseudo-second kinetic model rather than 0.0265 value of pseudo first order calculate.

Several authors reported that most metal sorption follow pseudo second order mechanism, thus, the sorption of $\mathrm{Ni}$ (II) ions onto seed oil shell follows the pseudo second order kinetic model.

3.5.2 Langmuir and Freundlich Isotherm Model

Both Langmuir's and Freundlich's adsorption isotherm equilibrium models were used for the analysis of the metal-adsorbent system. Langmuir model suggests monolayer sorption on a homogeneous surface without interaction between adsorbed molecules. Fig. 6 and fig. 7 shows the plots of $1 / \mathrm{qe}(\mathrm{g} / \mathrm{mg})$ versus $1 / \mathrm{C}_{\mathrm{e}}(\mathrm{L} / \mathrm{mg})$ and $\log \mathrm{q}_{\mathrm{e}}(\mathrm{mg} / \mathrm{g})$ versus $\log \mathrm{C}_{\mathrm{e}}(\mathrm{mg} / \mathrm{L})$, respectively.

The Langmuir linear equation below was used to calculate the maximum adsorption capacity of the adsorbent[18].

$\frac{1}{\mathrm{qe}}=\frac{1}{\text { bqmaxCe }}+\frac{1}{\mathrm{qmax}}(6)$

The essential features of the isotherm can be expressed in terms of a dimensionless constant separation factor $\left(\mathrm{K}_{\mathrm{L}}\right)$ that can be defined by the following relationship [19].

$\mathrm{K}_{\mathrm{L}}=\frac{1}{1+\mathrm{bCo}}(7)$

Where $\mathrm{C}_{\mathrm{o}}$ is the initial concentration $(\mathrm{mg} / \mathrm{L})$, while $b$ is the Langmuir equilibrium constant $(\mathrm{L} / \mathrm{mg})$. The value of separation parameter $\mathrm{K}_{\mathrm{L}}$ provides important information about the nature of adsorption. The value of $\mathrm{K}_{\mathrm{L}}$ indicated the type of Langmuir isotherm to be irreversible $\left(\mathrm{K}_{\mathrm{L}}=0\right)$, favorable $\left(0<\mathrm{K}_{\mathrm{L}}<1\right)$, linear $\left(\mathrm{K}_{\mathrm{L}}=1\right)$ or unfavorable $\left(K_{L}>1\right)$. It can be explained apparently that when $b>0$, sorption system is favorable [20].

The Freundlich isotherm is applicable to non-ideal adsorption on heterogeneous surfaces and the linear form of the isotherm can be represented as [21]: the isotherm model proposes a monolayer sorption with a heterogeneous distribution of active sites, accompanied by interactions between adsorbed molecules.

$\log \mathrm{qe}=\log \mathrm{K}_{\mathrm{f}}+\frac{1}{\mathrm{n}}\left(\log \mathrm{C}_{\mathrm{e}}\right)$

The adsorption constants $\left(\mathrm{K}_{\mathrm{f}}\right.$ and $\left.1 / \mathrm{n}\right)$ were obtained by plotting $\log \mathrm{q}$ against $\log \mathrm{C}_{\mathrm{e}}$, the Freundlich isotherm parameter $1 / \mathrm{n}$.

Table 1: pH dependent study of the sorption of Nickel (II) onto Pentaclethramacrophylla shell.

\begin{tabular}{lllll}
$\mathrm{P}^{\mathrm{H}}$ & $\mathrm{C}_{\mathrm{a}}(\mathrm{mg} / \mathrm{L})$ & $\mathrm{Co}_{\mathrm{e}}(\mathrm{mg} / \mathrm{L})$ & Sorption $\%$ & $\mathrm{q}(\mathrm{mg} / \mathrm{g})$ \\
\hline 3 & 5.51 & 94.49 & 94.49 & 2.36 \\
4 & 2.77 & 97.23 & 97.23 & 2.43 \\
5 & 2.49 & 97.51 & 97.51 & 2.44 \\
7 & 2.70 & 97.30 & 97.30 & 2.43 \\
8 & 2.17 & 97.83 & 97.83 & 2.45 \\
9 & 2.40 & 97.60 & 97.60 & 2.44 \\
\hline
\end{tabular}


Table 2:Langmuir and Freundlich isotherms paramerters for the adsorption of metal ions by Seed oil shel.

\begin{tabular}{|c|c|c|c|c|c|c|c|c|}
\hline \multicolumn{4}{|c|}{ Langmuir isotherm parameters } & & \multicolumn{4}{|c|}{ Freundlich isotherm parameters } \\
\hline $\mathrm{b}$ & & qmax & $\mathrm{K}_{\mathrm{L}}$ & $\mathrm{R}^{2}$ & $1 / \mathrm{n}$ & n & $\mathrm{K}_{\mathrm{f}}$ & $\mathrm{R}^{2}$ \\
\hline $\mathrm{Ni}$ & 0.127 & 19.724 & 0.7 & 0.87 & 0.83 & 1.208 & 4.282 & 0.9797 \\
\hline
\end{tabular}

Table 3: Pseudo first-order parameters for the sorption of Nickel (II) metal ion by PM shell

\begin{tabular}{lllll}
\hline Pseudo first & \multicolumn{1}{c}{ Order } & Parameters & & \\
\hline Metal & $\mathrm{q}_{\mathrm{e}}(\mathrm{cal}) \mathrm{mg} / \mathrm{g}$ & $\mathrm{K}_{\mathrm{l}}(\mathrm{g} / \mathrm{mg} \cdot \mathrm{min})$ & $\mathrm{R}^{2}$ & $\mathrm{q}_{\mathrm{c}}(\mathrm{exp}) \mathrm{mg} / \mathrm{g}$ \\
\hline $\mathrm{Ni}$ & 0.0265 & 0.0023 & 0.0021 & 2.441 \\
\hline
\end{tabular}

Table 4: Pseudo second- order parameters for the sorption of Nickel (II) metal ion by PM shell

\begin{tabular}{llllll}
\hline Pseudo & Second & \multicolumn{1}{c}{ Order } & Parameters & & \\
\hline Metal & $\mathrm{q}_{\mathrm{e}}(\mathrm{mg} / \mathrm{g} . \mathrm{min})$ & $\mathrm{h}(\mathrm{mg} / \mathrm{g} . \mathrm{min})$ & $\mathrm{K}_{2}(\mathrm{~g} / \mathrm{mg} \cdot \mathrm{min})$ & $\mathrm{R}^{2}$ & $\mathrm{q}_{\mathrm{e}}(\mathrm{exp}) \mathrm{mg} / \mathrm{g}$ \\
\cline { 2 - 6 } $\mathrm{Ni}$ & 2.4177 & -3.6761 & -0.6289 & 1 & 2.441 \\
\hline
\end{tabular}

Table 5: Effect of dosage on sorption of Ni (II) onto seed oil shell

\begin{tabular}{llll}
\hline $\begin{array}{l}\text { Dosage } \\
(\mathrm{mg} / \mathrm{g})\end{array}$ & $\mathrm{C}_{\mathrm{o}}(\mathrm{mg} / \mathrm{l})$ & $\mathrm{C}_{\mathrm{e}}(\mathrm{mg} / \mathrm{l})$ & Sorption \% \\
\hline 0.4 & 100 & 4.08 & 95.92 \\
0.8 & 100 & 3.45 & 96.55 \\
1.2 & 100 & 3.08 & 96.92 \\
1.6 & 100 & 2.59 & 97.41 \\
2.0 & 100 & 2.80 & 97.20 \\
\hline
\end{tabular}

Table 6: Table showing the data obtained for the time variation study of the biosorption of Ni metal ion using Pentaclethramacrophylla shell

\begin{tabular}{lllllll}
\hline Time(min) & $\mathrm{C}_{\mathrm{e}}(\mathrm{mg} / \mathrm{g})$ & $\mathrm{C}_{\mathrm{a}}(\mathrm{mg} / \mathrm{g})$ & $\mathrm{q}_{\mathrm{t}}(\mathrm{mg} / \mathrm{g})$ & $\mathrm{q}_{\mathrm{e}}-\mathrm{q}_{\mathrm{t}} \mathrm{mg} / \mathrm{g}$ & $\begin{array}{l}\mathrm{Log} \\
\mathrm{mg} / \mathrm{g}\end{array}$ & $\mathrm{qe}-\mathrm{q}_{\mathrm{t}} \mathrm{t} / \mathrm{q}_{\mathrm{t}}(\mathrm{gmin} / \mathrm{mg})$ \\
\hline 60 & 2.36 & 97.64 & 2.439 & 0.002 & -2.699 & 24.60 \\
90 & 2.43 & 97.57 & 2.442 & 0.000 & 0.000 & 36.87 \\
120 & 2.94 & 97.06 & 2.427 & 0.014 & -1.854 & 49.44 \\
150 & 2.65 & 97.35 & 2.434 & 0.007 & -2.155 & 61.63 \\
180 & 3.03 & 96.97 & 2.424 & 0.017 & -1.770 & 74.26 \\
\hline
\end{tabular}

\section{Conclusion}

Results obtained for the four critical examined conditions and from the mathematical kinetic models expression of the $\mathrm{Ni}^{2+}$ ion ontoseed oil shells, confirmed the good chemical reaction mechanism for the Hopseudo second-order and also equilibrium sorption Langmuir and Freundlich isotherm model fitted well. Meanwhile,this research work showed the excellent efficiency of powderedPentaclethramacrophyllashells in removal of $\mathrm{Ni}$ (II) ion from its aqueous solution. This also confirmed the importance, possibility and usefulness of known agricultural waste Pentaclethramacrophylla shell for theclean-up of heavy metals in industrial waste water.

\section{Acknowledgments}

Indubitable thanks are duly express to Dr. A.RIpeaiyeda of Chemistry Department University of Ibadan, Ibadan, Nigeria, for his tutelage role, direction and cooperation during the course of the research work and not forget Mrs. M.O John for her priceless words of encouragements and linkages for the brighter achievement of this work and irrefutable gratitude to my mummy for her undaunted support during the supply of the biomass.

\section{References}

[1] M.Malakootian, J. Nouri, ,andH. Hossiani, Removal of heavy metals from paint industries wastewater using Leca as an availableadsorbent.Int.J.Environ.Sci Tech.,(6) 2009, 183-190.

[2] Z. Aksu, U. Acikel, Modelling of a single-staged bioseparation process for simultaneous removal of iron (III) and chromium (VI) by using Chlorella vulgaris. Biochem. Eng. J.(4)2000, 229-238.

[3] S. Kang, J. Lee, K Kima, Biosorption of $\mathrm{Cr}(\mathrm{III})$ and $\mathrm{Cr}(\mathrm{VI})$ onto the cell surface of Pseudomonas aeruginosa, Biochem. Eng. J. (36) $2007,54-58$.

[4] F.A.A .Al-RubBiosorption of zinc on palm tree leaves: equilibrium, kinetics, and thermodynamics studies, Sep. Purif. Technol.( 41) 2006, 3499-3515. 
[5] C.E. Borba, R. Guirardello, E.A .Silva, M.T.Veit, and C.R.G. Tavares, Removal of nickel (II) ions from aqueous solution by biosorption in a fixed bed column: experimental and theoretical breakthrough curves, Biochem. Eng. J. (30) 2006, $184-191$.

[6] Hussein and K.Grennan, Identification of genes involved in metal transport in plants. J. plant Physio., 149 (4)2004,1623-1624.

[7] N. Kocberber, G. Donmez, Chromium (VI) bioaccumulation capacities of adapted mixed cultures isolated from industrial saline waste waters, Bioresour. Technol. (98) 2007, 2178-2183.

[8] M. Urak, LitteraJ. Sevc, M. Kolencik and S. Cernansky, Removal of arsenic (V) from aqueous solution using chemically modified sawdust of spruce (Piceaabies): Kinetic and isotherm studies .Int. J. Environ. Sci. Techol.,(6) 2009, $451-456$.

[9] J.C Igwe, Ogunewe and A.A Abia, Competitive adsorption of $\mathrm{Zn}$ (II),Cd (II) and $\mathrm{Pb}$ (II) ions from aqueous and non-aqueous solution by maize cob and husk. Afri. J. Biotechnol.,(4) 2005, 1113-1116.

[10] A.I Okoye, P.M Ejikeme, and O.D Onukwali, Lead removal from wastewater using fluted pumpkin seed shell activated carbon: Adsorption modeling and Kinetic .Int. J. Environ. Sci. Tech.,(7) 2010,793-800.

[11] N.A. Babarinde, J.O. Babalola and R.A. Saani, (2006)Biosorption of lead ions from aqueous solution by maize leaf. Int. J. Phys. Sci.,(1) 2006, 23-26.

[12] K.S. Low, and C.K. Lee, (1990) The removal of cationic dyes using coconut husk as an adsorbent. Pertanica,(13) 1990, $221-228$.

[13] F.E.Okieimen, and V.N. Onyenkpa, Removal of heavy metal ions aqueous solutions with melon (Citrullus vulgaris) seed husks. Bio. Waste, (29) 1989,11-16.

[14] A. Saeed, and M. Iqbal, Bioremoval of cadmium from aqueous solution by blackgram husk (Cicerarientinum).Water Res.,(37) 2003, 3472-3480.

[15] N. Gupta, S.S. Amritphale, N.Chandra, Removal of Zn (II) from aqeous solution by using hybrid precursor of silicon and carbon. Bioresour. Tech.( 101) 2010,3355 - 3362.

[16] A.H Mahvi, J. Nouri, G.A. Omrani, and F. Gholami, Application of Platanusorientalis leaves in the removal of cadmium from aqueous solution. World Applied Sci. J., (2) 2007, 40-44

[17] Y.SHo, J.C.Y. Ng, andG. McKay, Removal of lead (II) from effluents by sorption on peat using second-order kinetics. J. Sep. Sci. Tech.,36 (2) 2001,241-261.

[18] I. Langmuir, The adsorption of gases on plane surfaces of glass, mica and platinum, J. Am. Chem.,(57) 1918,1361-1403.

[19] T.S. Anirudhan, P.G. Radhakrishnan, J.chemhermodynamics(40) 2008, 703.

[20] W.N. Chen, C.H. Wu, E.K. James, and J.S. Chang, (2008) Metal biosorption capability of cupriavidustaiwanensis and its effects on heavy metal removal by nodulatedMimosa pudica, J. Hazard. Mater.(151) 2008,364-371.

[21] H.M.F. Freundlich, Liber die adsorption in lösungen.Zeitschrift fur PhysikalischeChemie,( 57) 1906, 385-470. 